\title{
Doing Field Work with Indigenous People in Brazilian Prisons
}

\author{
Gustavo Hamilton Sousa Menezes
}

Department of Anthropology, University of Brasilia, Brazil

Copyright $\bigcirc 2017$ by authors, all rights reserved. Authors agree that this article remains permanently open access under the terms of the Creative Commons Attribution License 4.0 International License

\begin{abstract}
In this article I intend to, first, make a brief overview of indigenous prisoners in Brazil, highlighting its invisibility by lack of accurate official records. Secondly, I want to address two indigenous perspectives on prisons; one from a people who, influenced by the Brazilian legal system, began to adopt prisons within Indigenous Lands as a sanction and punishment alternative to its members, and another from a people who reject the arrests considering them extremely cruel and contrary to their notions of human rights. Finally, I will point some conclusions reached by the anthropological work on the need to discuss public policies for Brazilian prisons that pay attention to the indigenous socio-cultural diversity.
\end{abstract}

Keywords Indigenous Prisoners, Brazilian Prisons, Field Work

\section{Introduction}

In 2012, an inmate escaped from a penitentiary in Hiroshima, Japan. The press reported the mobilization of about 800 police officers in the hunt for the fugitive, which was recaptured within hours. This escape aroused great national and international interest, since the last escape of a prisoner in Japan had taken place more than 20 years before.

This fact has been marked in my memory for referring a situation (and a relationship between prisoners and society) very different from the Brazilian situation. In Brazil, escapes and riots are very common, as well as violent deaths of inmates and workers of the prison system. Facts like these, though frightening, do not surprise the Brazilian population that often comes across to headlines of this nature in the news.

In February this year (2016) 10 prisoners have escaped, at once, the penitentiary complex called Papuda, which houses 14,000 prisoners. This complex is in Brasilia, the city where I live and from where I write to you. Five of those fugitives were convicted, among other practices, for murder. Most of them had sentences exceeding 30 years in prison. Weeks after the incident, several fugitives remain at large.

A few months before the mass escape, I have done field research in that penitentiary complex, along with a team from several institutions. I've observed the precarious working conditions of police and prison officers, as well as poor prison conditions to which detainees are subjected. Most Brazilian prisons have been defined by its low security, overcrowded cells, poor infrastructure, food and health care. Some prisons, in worse conditions, have been defined as contemporary versions of medieval dungeons.

Another prison where I conducted field research, the Agricultural Penitentiary Monte Cristo, in the state of Roraima, has had frequent riots and escape attempts for several years. There was an episode in 2015 when three prisoners were killed by other prisoners, one of whom was beheaded and had his head hanging on incarceration.

Given this situation, there is an inevitable question: Why does an anthropologist do field work in places like these? In my case, it is working with the Brazilian indigenous peoples, known in Brazil as Índios that leads me to research prisons. My doctoral studies are in ethnology and for many years, I dedicated myself to the research and development of Anthropological Reports, made at the request of Justice, describing the socio-cultural situation of indigenous people who appeared as defendants in criminal proceedings. To prepare these reports, it is necessary to interview the defendants, their families and key figures of the indigenous community. Since part of these defendants was arrested even before the trial, many of the interviews were conducted in prisons.

In this article I intend to, first, make a brief overview of indigenous prisoners in Brazil, highlighting its invisibility by lack of accurate official records. Secondly, I want to address two indigenous perspectives on prisons; one from a people who, influenced by the Brazilian legal system, began to adopt prisons within Indigenous Lands as a sanction and punishment alternative to its members, and another from a people who reject the arrests considering them extremely cruel and contrary to their notions of human rights. Finally, I will point some conclusions reached by the anthropological work on the need to discuss public policies for Brazilian 
prisons that pay attention to the indigenous socio-cultural diversity.

\section{Method}

The method consisted of visits to penitentiaries for talks, interviews and the application of a standard form to indigenous prisoners. Access to prisoners by researchers is not a simple thing in Brazil, since most prison directors prefer not to make public the precarious situation of the institutions they command. However, this research was carried out in partnership with the National Penitentiary Department, which has as one of its attributions to carry out inspections in the prison units, a fact that guaranteed us access to the facilities and the prisoners for several consecutive days in each stage.

I worked as an anthropologist research coordinator, accompanied by other public officials of organs such as the National Indian Foundation and the Penitentiary Department. In prisons where the number of indigenous people was very high, as in the city of Dourados, in the state of Mato Grosso do Sul, where the indigenous prison population reached 100 individuals, the team was divided into three pairs of interviewers, with the aim of more interviews, so that all the natives could be heard. Each interview lasted from 30 minutes to an hour, depending on the Indian's interest in telling his story. Each pair of interviewers could hear between 8 and 10 Indians per day, so the survey in Dourados, for example, lasted about a week to complete.

The form was divided into the following sections: ethnicity, personal data, procedural data, citizenship, housing, education, work, legal situation, incarceration situation (cell condition) and knowledge of the law. The self-declaration was considered sufficient by the research team to consider the individual as indigenous, as recommended by Convention 169 of the International Labor Organization, to which Brazil is a signatory.

Based on the data collected, it was possible to confirm that, although the Indians constitute a specific group, the State does not allow them different treatment. As the vast majority of indigenous people do not have the financial resources to pay a private lawyer, they are almost always defended by public defenders. However, the public defenders, as a whole, do not know the indigenous reality and produce pieces of defense without taking into account the cultural difference of the Indians. There are very common cases where public defenders prepare defense texts without even talking to indigenous defendants, in a clear violation of human rights.

More than knowing the structure and routine of a "total institution" [1], or addressing the problem that human societies and public authorities face with correctional institutions [2], our intention was to understand how indigenous societies are perceived and how they interpret the national legal system, from their own point of views.

\subsection{Imprisoned Indigenous: a Brief Overview}

Currently, Brazil's indigenous population totals approximately 820,000 individuals, represented in 305 different people [3]. There are registered in the country 274 indigenous languages. It was also found that the significant number of $17.5 \%$ of the indigenous population does not speak Portuguese.

Also noteworthy is that indigenous peoples are not in uniform situations. They are highly diverse due to their different historical, geographical, environmental, economic and socio-cultural situations. In Brazil, there are examples of people with hundreds of years of contact with the surrounding society, as well as other fully isolated from contact with it.

In general, the indigenous population is facing an accelerated and complex social transformation, seeking new answers to their physical and cultural survival. Indigenous communities face specific problems, such as territorial invasion, environmental degradation, sexual exploitation, drug abuse, labor exploitation, including children labor, disorderly rural exodus, causing large concentration of indigenous peoples in cities at risk.

In addition to the immigration to urban areas, it is known that the native Brazilians are increasingly present in the prison population of the country [4]. According to the National Penitentiary Department -DEPEN, had, in December 2010, a total of 748 (seven hundred and forty-eight) internal indigenous people in the prison system, 56 (fifty six) women and 692 (six hundred ninety-two) men.

It is known, however, that this estimate is not precise, and, in fact, quite undersized. But why this underreporting occurs? It occurs mainly because of "ethnic mischaracterization" suffered by Indians in prisons, since the indigenous identity of these people have been treated with little or no importance by managers of the prison system, which, as a rule, are not oriented keep records on ethnic diversity. A consequence of this is the legal invisibility of the Indians in the statistics and in the legal sphere [5]. There is no general formulary of entry into the prison system that identifies citizens as indigenous and as belonging to a specific people. Thus, the workers of penitentiaries frequent and deliberately include the indigenous in the category "brown", a fact that results in the denial of differentiated rights to them. One must also consider the common fear of indigenous people identifying themselves as such, due to the negative experiences they have had before, such as aggression and humiliation.

In a recent joint survey conducted by the National Penitentiary Department and the National Indian Foundation (FUNAI) at the Agricultural Penitentiary of Monte Cristo, in the city of Boa Vista, Roraima state, the difference between the number of indigenous initially recognized by the institution and the number that was found after a more thorough count (based on self-declaration) was almost $100 \%$. While the official data pointed 70 indigenous in this prison, our field survey registered 139 .

This invisibility makes the prison system even more 
difficult for the Indians because they have some of their basic human rights denied, such as the right to have an interpreter in their mother tongue and the right to religious freedom, for example. In fact, the Indigenous criminal matter arouses doubts and questions not only among the indigenous people but also among the operators of law.

Among the indigenous, what stands out is the lack of educational programs that provide understanding and help them to internalize rules and conducts. There is a lack of understanding on administrative and legal processes. Fell of them know that they have the right to interpreters and to free public defenders, among others.

About the operators of law, there are few who have some more solid training on indigenous issues. Added to this is the fact that the two main laws relating to indigenous issues - the Federal Constitution and the Statute of the Indio - are fruits of different, and in many cases divergent, paradigms [6].

While the Constitution recognizes the right of Indios to be Índios and remain as such regardless of their socio-cultural changes, the Indio Statute is linked to the integrationist ideology, understanding the condition of indigenous as something transient. A large portion of operators of law remains linked to the integrationist vision, and has difficulty in accepting that the meaning of social offenses varies from society to society. Brazilian anthropologists, for several decades, have been trying to raise awareness in the legal sphere to this diversity, giving subsidies to operators of law to understand the "other". Alcida Ramos is an anthropologist who worked in this direction. In a text to a broader public, she wrote as follows:
"Community life of a village is not immune of creating conflicts, disputes, anti-social behavior in different degrees of severity and disapproval. The social group reacts to it according to cultural standards recognized by everybody, not only from a given village but also from the entire society. The definition of what is a social offense varies from society to society. While in some societies murder is severely punished, in others it is considered private matter of the people involved. Adultery can result in social sanctions against adulterers, or can stay only between husband, wife and the third. The break of incest taboo can bring offenders to more or less severe penalties; the practice of witchcraft can be only verbally disapproved or may result in the summary execution of the alleged sorcerer. Each society has its cast of 'crimes', which are the responsibility of the group and not just domestic issues, and also has a list of appropriate punishments for these crimes. "[7]

Recognition of an extensive indigenous cultural diversity implies the recognition of a wide range of moral interpretations of marriage arrangements, living arrangements, values and symbols related to the body, violence, purity, to the spiritual world, to the concepts of life and death, on the behaviors more or less valued, on prohibitions and sanctions. It also means recognizing that conflicts, disputes, and various anti-social behaviors occur in all societies, but the actions and behaviors that are disapproved, according to greater or lesser degree, vary widely.

\section{As pondered Laraia:}

"When dealing with the relationship between culture and law in Brazil, one cannot leave out the indigenous question, because of peculiarities due to the effects of article 231 of the Federal Constitution, which recognizes the indigenous rights relating to their social organization and their customs, languages, beliefs and traditions. Recognize them corresponds to the acceptance by the State of territorial pockets where Brazilian laws are not fully implemented". [8]

Therefore, recognizing indigenous cultures and societies is to recognize a wide range of behavior, perspectives and opinions. This requires a reordering of the legal sphere that goes beyond the rhetoric and reaches practice.

\section{Discussion}

The transformations through which native populations pass through the process of contact with colonial states have been the focus of many studies [9]. Sahlins [10], for example, shows the records of the Hawaiian courts of the 1830s and 1840s, when a new code of laws, inspired by puritanical morality, was imposed. Conducts that were considered normal and acceptable by the natives, especially those related to sexual behavior, were harshly condemned by the new code of laws, resulting in a large number of convictions. The Brazilian reality bears similarities, since many condemnations of indigenous men are due to consensual sexual practices with women between 12 and 14 years old, a serious crime for the Brazilian authorities, but a practice considered normal among many indigenous peoples. Thus, through the condemnation of indigenous individuals, and not through dialogue and educational guidance, the State seeks to change the indigenous culture, thought and conduct they deem to be reprehensible.

\subsection{Indigenous Peoples Appropriating the Legal System and Adhering to Prisons}

The social organization and the rules of a particular society never, or almost never, come from a completely autonomous social development. Systems are changed, influenced by several other ethnic groups and societies. In Brazil, the biggest influence to indigenous rules and principles of justice is undoubtedly the Brazilian law. On the one hand, there is an uneasy relationship between indigenous legal systems and national law, on the other; from the national law many indigenous systems draw several of their contemporary standards [11].

This is the case of the Kaingang indigenous people, speakers of language from linguistic branch Jê and inhabitants of the southern states of Brazil. The Kaingang 
people, throughout their process of contact, absorbed, processed and reworked some ideas and concepts from the surrounding society, making it theirs. Arrests, for example, were not part the punishments range of Kaingan but currently are present in most of lands and indigenous reserves of this people. In addition, positions of authority, such as the captain and soldier, were incorporated into their organization,

The Kaingang, as has been pointed out by numerous studies, have a highly hierarchical political structure [12]. The maximum position of this hierarchy is occupied by the cacique, followed by vice-cacique. The vice-cacique is not a mere adjunct of the decisions taken by the cacique, enjoying prestige and responsibilities comparable to those of the cacique. In the traditional model, according to their elders, cacique and vice-cacique should belong to opposite moieties; this rule is still followed in some Kaingang lands - the Kaingang say that only with individuals from the opposite half it is possible to plan political actions; the penalties on the other hand, are usually applied by individuals from the same half. There is therefore a concept of complementarity among these positions.

The duties of the cacique and the vice-cacique involve both the representation of the community to the world of the white authorities, and decisions of internal dynamics. For Kaingang, in general, the political authority of their chiefs is directly related to the ability of these caciques well represent their community. Therefore, they expect the authority of the caciques exceeds the limits of the Indigenous Land. In other words, it is important that the indigenous authority is also an authority on the 'white world'. There are several cases where the caciques combine these two attributes being, at the same time, chiefs and city council members in neighboring municipalities.

The participation of the chief and deputy chief in the internal dynamics of the Indigenous Land is related to decision-making processes related to economic, political, legal and ethical. Such decisions involve the participation of other Kaingang authorities, those that generally are called "leadership", which form a sort of local council. Besides the cacique and the vice-cacique, the remaining members of the leadership are individuals that have specific functions, sometimes related to social control (called 'soldiers', 'officers', 'sergeants'), sometimes related to the decision-making processes (called captains and counselors).

Just as there is a hierarchical structure in political positions, also there is a hierarchy in decision-making. The soldiers, officers and sergeants are responsible for the resolution of minor problems, such as infighting, drunkenness, accusations of petty theft and disrespect for authority. Decisions are taken in meetings, usually in front of the village chief's house, in which offenders expose their motives and leaders argue seeking conciliation. The punishments imposed on offenders vary depending on the crime or infraction. In the past, the Kaingang are notorious for applying extreme punishments to offenders [13]. The best known of these punishments was the 'trunk', in which the offender has his feet tied. With the establishment of the Indigenous Posts within the Kaingang land, in the 1940s, the 'trunks' were largely replaced by prisons. Even today, however, the 'trunk' is used in some Indian lands. There are cases where offenders accused of crimes are either tied to a tree (usually for enough time to 'cure binge drinking'), or are arrested without the right to bathing and feeding - receive only water - or, in more severe cases, they are transferred to other Indigenous Land. Punishments rarely exceed three days, but there are cases of detention for up to a month. In cases of less importance, offenders are asked to provide services to the community, like to clean the roads and access to school or health clinic.

Nevertheless, often the community chooses to send the accused member to be judged by the national justice. The victim or the affected part, in general, claims this attitude. In Kaingang vision, the judgement and the punishment by the Brazilian justice will be heavier and will not be manipulated by indigenous community internal alliances. Thus, transforming their rules and incorporating the values of national society, the Kaingang manage to use two systems internal and external - according to the situation, and to the political pressures involved to it.

\section{Findings}

\subsection{Indigenous Peoples who Reject Prisons: Other Human Rights Concepts}

Some indigenous peoples respond to the forces of interethnic relations by transforming their conceptions of justice and adhere to the national legal system, incorporating values and punishments that were strangers to them. However, other peoples insist on maintaining their traditional practices and vehemently reject some principles of the Brazilian legal system, including prisons. One of these people is the Maxakali, speaker of language from the linguistic branch macro-Ge, resident at the state of Minas Gerais, in southeastern Brazil.

The Maxakali society is a markedly closed indigenous society, whose striking feature is the ability to preserve over centuries of contact - their language and the main elements of their culture, such as kinship, cosmology and religion. Although the members of this ethnic group have knowledge and sometimes attending the surrounding society, their behavior, worldview and self-determination are driven largely by values and sanctions of their own Maxakali culture.

Because of the maintenance of these social structures, spatial planning of Maxakali traditional villages remains the same as described since the nineteenth century by travelers, administrators and military. There are simple houses distributed around a square where there are ceremonial poles through which descend the spirits of the dead (the yãmiy); with the "house of religion" on one side of the square and the leader's house in the other. 
The Maxakali social life is completely punctuated by rites. Many of them are made to prevent or cure diseases because they are interpreted as the result of a voluntary intervention of spirits that reach or capture people's soul, causing them to get sick. The healing rituals aim to restore the physical and spiritual balance by pleasing the evil spirits. These rituals are led by the spiritual leader of the group. Accompanied by his relatives, the spiritual guide sings, dances and asks to the patient information about the spirit that haunts him, while ask to the spirit what needs to be satisfied. Once this step is done, men go back to the house of religion to adopt the necessary measures to continue the work. Having obtained all the necessary, the spiritual leader and the group return to the patient, promoting new session of chanting and prayers and launching large puffs of smoke on it. They request the spirits to retreat.

The death and its possible consequences are also seen as responsible for the social imbalance, because the spirit of the dead - yãmiy - can cause diseases or turn into animal and attack the group. To control the evil entities the religious leader needs strength and great ancestral knowledge. Maxakali society regards these ceremonies as acts of great social dimension so much that the healing rituals must be performed in group and with the support of spirits regarded as beneficent. The isolated practice of rituals carried by one only member of the community is considered as an anti-social act, and is interpreted as practice of witchcraft, which can lead to the execution of the suspect.

For Maxakali, most punishments come down to three categories: ostracism, banishment and death. For minor cases of antisocial behavior, ostracism or public disapproval is often used. In more severe cases, the community apply the banishment of the member whose behavior and actions are considered incompatible and unacceptable. In extreme cases, Maxakali exercise justice through mutual death. A researcher, for example, noted that "the victim's relative has the right and responsibility to 'pay' for his death, killing one held responsible" [14]. One can see, therefore, that Maxakali have a cultural code that, by previewing revenge, seeks to promote the inhibition of aggressive manifestation among its members. When aggressive manifestation is not inhibited and murder takes place, the death of the offender is seen as the attitude to be taken to restore the social balance.

I visited a Maxakali in a prison in the state of Minas Gerais. He understood very little of the Portuguese language. In prison, he never had an interpreter, not even when his testimony was taken. To interview him, I counted on support from a servant of FUNAI who understood the Maxakali language. The prisoner had a certain position in the ritual life and his absence was paralyzing the entire community. Everything was suspended and there was no way to replace it unless considering him dead, and that they could not do. Thus, the safety and health of the entire community was in danger.

During the interview, the prisoner said he was very ill and he needed spiritual treatment. However, in Brazilian prisons, indigenous cultural diversity is rarely respected or taken into account. Prisons usually only admit Christian priests or ministers visiting the prisoners. Other religions, however, such as from African-Brazilian or indigenous origin suffer great discrimination and rarely receive permission to be professed.

The indigenous prisoner was accused of attempted rape. The victim's family was very angry and persuaded the community to apply to him - as soon as he returned to the village - the traditional sentence of banishment. Despite this outrage, the victim's relatives agreed with the relatives of the prisoner in one important aspect; to both sides the punishment of imprisonment was deemed unsuitable, to be seen as cruel and exaggerated. In fact, many Maxakali consider that the arrest is a prelude to death. I heard several times the following phrase coming from different members of different communities: "No Maxakali can get stuck in prison, there he cannot live." They say it because they believe deeply that stuck a Maxakali cannot access the Yãmiy spirits or participate in rituals that heal and balance the person, what starts a weakening process which culminates in death. Therefore, the victim's relatives were concerned that if the arrested Maxakali did not survive, his death would trigger revenge by the relatives of the prisoner against them.

It is clear, therefore, that the prison is not part of the range of punishments applied by the community. And more than that, the idea that a Maxakali is being held away from his people fills with horror all the other members of that people, even those who are at odds with him. Using an analogy, one can say that for the Maxakali cultural patterns prison is such an excessive and unacceptable punishment as it would be slavery to the cultural standards of the national society.

These facts demonstrate that Maxakali society with regard to justice, keeps essentially closed to the surrounding society, using almost exclusively their traditional conceptions to seek social balance. Maxakali conceptions of justice may be seem extreme and cruel to members of the national society, however, the reverse is also true, as for Maxakali the seclusion in prisons, for example, is viewed with horror by all because it is considered an extreme measure that borders on inhumanity.

\section{Final Considerations}

The constitutional recognition that indigenous peoples have the right to their own social organizations should have guided in Brazil a different policy in relation to justice, especially regarding the application by the indigenous peoples of their traditional systems of law for conflict resolution. However, indigenous people almost never find a positive atmosphere in the national legal system to develop its legal sensitivities.

Because of this, many peoples, instead of using their own methods of conflict resolution, end up by copying the organization of the surrounding society as a political strategy to be recognized by national justice. This is the case of the Kaingang people, who implemented its own police forces 
and prisons, as well as established written internal rules typifying illicit conduct and setting punishments. Other peoples, like Maxakali, try to stay closed to national society and seek to resolve their disputes according to their own rules and concepts.

Nowadays, agreeing or not with (and understanding or not) national law, the majority of indigenous people come to know the reality of having some of its members imprisoned. The increase in the number of indigenous people incarcerated draws attention to the urgent need to ensure differentiated physical and cultural conditions in prisons, in order to promote human dignity of these people.

Based on interviews and contacts with indigenous prisoners, I pointed some measures that I consider important:

1) Interpreter service for defendants and indigenous prisoners who do not have full knowledge of Portuguese language.

2) Specialized medical care to indigenous prisoners due to the proven vulnerability of this population to diseases and epidemics

3) Right of access to traditional food.

4) Right of religion expression, including right of meeting with spiritual leader.

5) Adaptation of national calendar and holidays to ceremonial and commemorative calendar of the different indigenous peoples, so that the Indian prisoner can choose to receive benefits from temporary exits on dates that are more consistent with their community reality.

Reflection on the incarcerated indigenous people is recent in Brazil and is being gradually incorporated into the agenda of anthropologists, indigenous movements and indigenous institutions. Friederes and Robertson's studies [15] on the Canadian justice system, as being racially discriminatory, can be easily applied to the Brazilian reality. Moreover, it is a system designed to make cultural differences invisible [16]. Our research shows that if Brazilian prisons are considered atrocious for non-indigenous citizens, for the indigenous it is even worse. In this context, some changes are necessary; considering the cultural difference is not a matter of privilege but a matter of dignity and human rights.

\section{REFERENCES}

[1] GOFFMAN, Erving. Asylums: essays on the social situation of the mental patiente and other inmates. Anchor Books. 1961.
[2] FOULCAULT, Michel. Discipline and Punish: the birth of the prison. Pantheon Books. 1977.

[3] IBGE, Instituto Brasileiro de Geografia e Estatística. 2010.

[4] UNITED NATIONS, A/hrc/27/48/Add.3, Summary, 2014.

[5] ABA-Associação Brasileira de Antropologia \& PGR-Procuradoria Geral da República. Criminalização e Situação Prisional de Índios no Brasil. Edital Projeto de Pesquisa ESMPU nº 19/2006. Relatório Final. Brasília: ABA, 2008 .

[6] MILLER, Bruce \& MENEZES, Gustavo. "Anthropological Experts and the Legal System: Brazil and Canada." In The American Indian Quarterly, Volume 39, Number 4, Fall 2015, p. 391-430 (Article) Published by University of Nebraska Press. 2015.

[7] RAMOS, Alcida Rita. Sociedades Indigenas. Editora Ática S.A., São Paulo. pp. 61, 1994.

[8] LARAIA, Roque de Barros. "Cultura". In: SOUZA LIMA, A. C. de (org.) Antropologia e direito: temas antropológicos para estudos jurídicos. Brasília, Contra Capa, LACED/ABA. :64, 2012.

[9] MILLER, Bruce. The problem of justice: tradition and law in the Coast Salish world. University of Nebraska Press, 2001;

[10] GEERTZ, Clifford. After the fact: two countries, four decades, one anthropologist. Harvard University Press. 1995;

[11] DICKASON, Olive Patricia. Canada's first nations: a history of founding peoples. University of Oklahoma Press. 1992

[12] SAHLINS, Marshall. Island of History. University of Chicago. 1985.

[13] VILLARES, Luiz Fernando. "Direito Penal na Ordem Jurídica Pluriétnica", Em: Direito penal e povos indígenas. Villares, L. F. (Coord.), Curitiba: Juruá, pp. 16. 2010.

[14] BALDUS, Herbert. O culto aos mortos entre os Kiangang de Palmas. In: Ensaios de etnologia brasileira. São Paulo : Ed. Nacional ; Brasília : INL, p. 8-33. (Brasiliana, 101). 1979.

[15] RAMOS, Luciana. VÉNH JYKRÉ e KE HÁ HAN KE: permanência e mudança do sistema jurídico dos kaingang no Tibagi. Tese de Doutorado em Antropologia Social. Universidade de Brasília - pp. 183-4. 2008.

[16] POPOVICH, Francês. A Organização Social dos Maxakali. Dissertação apresentada ao Departamento de Sociologia da Universidade do Texas. Impresso pela Sociedade Internacional de Lingüística. Brasília-DF e Cuiabá-MT. 1980.

[17] FRIEDERES, J. and B. Robertson. "Aboriginals and the Criminal Justice System: Australia and Canada." In International Journal of Contemporary Sociology, 31, 1: 1-27. 1994.

[18] MILLER, Bruce. Invisible indigenes: the politics of nonrecognition. University of Nebraska Press, 2003. 